\title{
Redefining the disease locus of 16q22.1-linked autosomal dominant cerebellar ataxia
}

\author{
Takeshi Amino $\cdot$ Kinya Ishikawa $\cdot$ Shuta Toru $\cdot$ Taro Ishiguro $\cdot$ Nozomu Sato $\cdot$ \\ Taiji Tsunemi $\cdot$ Miho Murata $\cdot$ Kazuhiro Kobayashi · Johji Inazawa $\cdot$ Tatsushi Toda \\ Hidehiro Mizusawa
}

Received: 31 January 2007/Accepted: 2 May 2007 / Published online: 5 July 2007

(C) The Japan Society of Human Genetics and Springer 2007

\begin{abstract}
The 16q22.1-linked autosomal dominant cerebellar ataxia (16q-ADCA; Online Mendelian Inheritance in Man [OMIN] \#117210) is one of the most common ADCAs in Japan. Previously, we had reported that the patients share a common haplotype by founder effect and that a C-to-T substitution $(-16 \mathrm{C}>\mathrm{T})$ in the puratrophin-1 gene was strongly associated with the disease. However, recently, an exceptional patient without the substitution was reported, indicating that a true pathogenic mutation might be present elsewhere. In this study, we clarified the disease locus more definitely by the haplotype analysis of families showing pure cerebellar ataxia. In addition to microsatellite markers, the
\end{abstract}

T. Amino $\cdot$ K. Ishikawa $(\bowtie) \cdot S$. Toru $\cdot$ T. Ishiguro

N. Sato $\cdot$ T. Tsunemi $\cdot$ H. Mizusawa $(\bowtie)$

Department of Neurology and Neurological Science, Graduate School, Tokyo Medical and Dental University,

1-5-45 Yushima, Bunkyo-ku, Tokyo 113-8519, Japan

e-mail: kishikawa.nuro@tmd.ac.jp

H. Mizusawa

e-mail: h-mizusawa.nuro@tmd.ac.jp

M. Murata

Department of Neurology, Musashi Hospital,

National Center of Neurology and Psychiatry,

Tokyo, Japan

K. Kobayashi · T. Toda

Division of Clinical Genetics, Department of Medical Genetics, Osaka University Graduate School of Medicine,

Osaka, Japan

J. Inazawa

Department of Molecular Cytogenetics,

Medical Research Institute and School of Biomedical Science,

Tokyo Medical and Dental University, Tokyo, Japan single nucleotide polymorphisms (SNPs) that we identified on the disease chromosome were examined to confirm the borders of the disease locus. The analysis of 64 families with the $-16 \mathrm{C}>\mathrm{T}$ substitution in the puratrophin-1 gene revealed one family showing an ancestral recombination event between SNP04 and SNP05 on the disease chromosome. The analysis of 22 families without identifiable genetic mutations revealed another family carrying the common haplotype centromeric to the puratrophin-1 gene, but lacking the $16 \mathrm{C}>\mathrm{T}$ substitution in this gene. We concluded that the disease locus of 16q-ADCA was definitely confined to a 900-kb genomic region between the SNP04 and the $-16 \mathrm{C}>\mathrm{T}$ substitution in the puratrophin-1 gene in 16q22.1.

Keywords 16q-ADCA - Pure cerebellar ataxia . Haplotype $\cdot$ SNP $\cdot$ Founder effect $\cdot$ SCA4

\section{Introduction}

Autosomal dominant cerebellar ataxia (ADCA) is a clinical entity of heterogeneous neurodegenerative diseases that show dominantly inherited, progressive cerebellar ataxia that can be variably associated with other neurological and systemic features (Harding 1982). ADCA is now classified by the responsible mutations or gene loci. Subtypes of ADCA of which causative genes or gene loci have been identified are known as spinocerebellar ataxia type (SCA) 1, 2, 3 (or Machado-Joseph disease), 4-8, 10-19, 21-23, $25,26,28$, dentatorubral and pallidoluysian atrophy (DRPLA), and ADCA with mutation in the fibroblast growth factor (FGF) 14 gene (Schöls et al. 2004; Yu et al. 2005; Cagnoli et al. 2006).

Among these, mutations in SCA1, SCA2, SCA3/MJD, SCA6, SCA7, SCA17, and DRPLA have been identified as 
the expansions of a trinucleotide (CAG) repeat that encodes the polyglutamine tract, uniformly causing the aggregation of polyglutamine-containing causative protein (Ross and Poirier 2004). The expansion of noncoding trinucleotide (CAG or CTG) or pentanucleotide (ATTCT) repeats are involved in SCA8, SCA10, and SCA12 (Holmes et al. 1999; Koob et al. 1999; Matsuura et al. 2000). Very few families are affected by missense mutations in beta-III spectrin (SPTBN2) (SCA5 (see Ikeda et al. 2006)), voltage-gated potassium channel KCNC3 (SCA13 (see Waters et al. 2006)), protein kinase C gamma (PKC gamma) (SCA14 (see Chen et al. 2003)), and FGF14 genes (ADCA with FGF14 mutation (see van Swieten et al. 2003). However, genes or even loci remain unidentified for $20-40 \%$ of families with ADCA (Sasaki et al. 2003).

We had previously found that Japanese families with ADCA map to the human chromosome 16q22.1 (16qADCA), the gene locus of SCA4 (Flanigan et al. 1996; Hellenbroich et al. 2005; Nagaoka et al. 2000). However, our families show clinically pure cerebellar ataxia without other neurological signs, such as sensory neuropathy or pyramidal tract signs seen in SCA4. All 16q-ADCA patients shared a common haplotype, presumably due to inheritance from a disease chromosome of a founder (Takashima et al. 2001). Our haplotype analysis of 52 families with DNA polymorphic microsatellite markers revealed that they all share a common haplotype for the 400-kb genomic region in 16q22.1 (Ishikawa et al. 2005). Within this region, we found that a heterozygous single nucleotide C-to- $\mathrm{T}$ substitution $(-16 \mathrm{C}>\mathrm{T})$ in the untranslated region of the puratrophin-1 gene was entirely segregated with all patients, suggesting a strong association with the disease. This substitution was also found in other cohorts of Japanese families with ataxia (Ouyang et al. 2006; Onodera et al. 2006), while it was not found in Caucasian patients in Europe (Wieczorek et al. 2006). The frequency of $16 \mathrm{q}-\mathrm{ADCA}$ is considered to be relatively high in Japan, counted as the third or fourth major subtype of ADCA after MJD, SCA6, and DRPLA (Takano et al. 1998; Sasaki et al. 2003; Ohata et al. 2006).

However, one group recently reported an exceptional patient without the $-16 \mathrm{C}>\mathrm{T}$ substitution in the puratrophin1 gene, in a family in which all of the other affected subjects carried the substitution (Ohata et al. 2006). This patient shared the common haplotype in a region centromeric to the substitution in the puratrophin-1 gene, suggesting that a true pathogenic mutation may be present in a different gene lying centromeric to the $-16 \mathrm{C}>\mathrm{T}$ substitution in the puratrophin-1 gene. Moreover, other patients sharing the common haplotype centromeric to the substitution in the puratrophin-1 gene without the substitution might exist.

In this study, we re-examined the haplotype of families showing ataxia in order to clarify a common genomic re- gion shared in all 16q-ADCA patients. Because slippage mutation might cause minor deviations in repeat size for microsatellite markers (Ikeda et al. 2004), single nucleotide polymorphisms (SNPs) detected by ourselves on the disease chromosome were used in the analysis to confirm recombinant regions that are not conserved among families.

\section{Materials and methods}

Haplotype analysis

DNA samples from patients showing ataxia referred to our department were examined. After informed consent was obtained, genomic DNA was extracted from peripheral blood lymphocytes or lymphoblastoid cell lines by the use of methods described elsewhere (Ishikawa et al. 1997). All families were excluded for SCA1, SCA2, SCA3/ MJD, SCA6, SCA7, SCA8, SCA12, SCA14, SCA17, and DRPLA by testing for mutations in the disease genes.

Firstly, common haplotypes of the 16q-ADCA families with the $-16 \mathrm{C}>\mathrm{T}$ substitution in the puratrophin-1 gene were analyzed. Genotypes were determined for 19 microsatellite markers (D16S3043, D16S3031, D16S3019, CTATT01, TAGA02, GGAA05, D16S397, GGAA10, GATA01, D16S421, TA001, GA001, 17 msm, D16S3107, GGAA01, CTTT01, GT01, D16S3095, D16S512) in $16 q 22.1$ by the use of methods described elsewhere (Ishikawa et al. 2005). Compared to our previous study (Ishikawa et al. 2005), several new markers with high specificity to the 16q-ADCA chromosome were added and the region analyzed was expanded to beyond the previous critical region spanning GATA01 and $17 \mathrm{msm}$ (Ishikawa et al. 2005) in order to determine the maximum genomic region conserved in all of the affected individuals from all of the families. Although the phase of the markers were not confidently determined in families that have only a few examined members, the possibility that they carried the haplotype was indicated in those cases.

Secondly, haplotypes of families without the $-16 \mathrm{C}>\mathrm{T}$ substitution in the puratrophin-1 gene were also analyzed to see if they had the common haplotype centromeric to the substitution in the puratrophin-1 gene. Their genotypes were determined for 14 markers (D16S3043, D16S3019, CTATT01, TAGA02, GGAA05, D16S397, D16S3086, GATA01, GA001, 17 msm, CTTT01, GT01, D16S3095, D16S512), which are relatively highly specific to the common haplotype in 16q-ADCA.

Single nucleotide polymorphisms

We searched for single nucleotide polymorphisms (SNPs) on the disease chromosome by ourselves because most of 
Table 1 The haplotype analysis of 16q22.1-linked autosomal dominant cerebellar ataxia (16q-ADCA) families with the -16CT substitution of the puratrophin-1 gene. The gray squares indicate that the alleles are one repeat-unit different fromthe common allele of 16q-ADCA and the black squares indicate alleles with two or more repeat-unitdifferences. One repeat-unit difference was seen for markers D16S397, GGAA10,GATA01, and TA001, close to the puratrophin-1 gene in several families, and greaterrepeat-units differences were observed for GGAA05 and other centromeric markers. Similarly, greater repeat-units differences were observed for $17 \mathrm{msm}$ and markers lyingtelomeric to $17 \mathrm{msm}$. n.e. $=$ not examined

\begin{tabular}{|c|c|c|c|c|c|c|c|c|c|c|c|c|c|c|c|c|c|c|c|c|c|c|c|c|}
\hline Marker & $\begin{array}{c}\text { most } \\
\text { common } \\
\text { haplotype }\end{array}$ & $\begin{array}{c}\text { family No. } \\
\text { frequency } \\
\text { in control } \\
(\%)\end{array}$ & $\underline{\mathbf{P 2}}$ & $\underline{\mathbf{P 4}}$ & $\underline{\mathbf{P 1 4}}$ & $\underline{\mathbf{T 2}}$ & $\underline{\mathrm{T3}}$ & $\underline{\text { T4 }}$ & $\underline{T 5}$ & $\underline{\text { T6 }}$ & $\underline{\mathbf{T 7}}$ & $\underline{T 12}$ & $\underline{T 15}$ & $\underline{T 19}$ & $\underline{T 21}$ & $\underline{T 25}$ & $\underline{T 26}$ & $\underline{T 28}$ & $\underline{\text { T30 }}$ & $\underline{T 37}$ & $\underline{\mathbf{T 4 2}}$ & $\underline{\mathbf{T 4 3}}$ & T44 & $\underline{\text { T46 }}$ \\
\hline D16S3043 & 1 & 25.0 & 1 & $1 / 6$ & 7 & 5 & 8 & 1 & $1 / 8$ & 1 & $1 / 5$ & 5 & $1 / 7$ & n.e. & $1 / 8$ & n.e. & n.e. & 1 & n.e. & 1 & n.e. & $1 / 5$ & $1 / 5$ & 1 \\
\hline D16S3031 & 9 & 68.1 & 9 & 9 & 9 & 9 & 9 & 9 & 10 & 1 & 10 & 9 & $9 / 10$ & 9 & 9 & 9 & 9 & $1 / 9$ & 9 & 9 & 9 & 9 & 9 & 9 \\
\hline D16S3019 & 4 & 41.4 & 4 & 4 & 4 & 4 & 4 & $4 / 5$ & $3 / 4$ & $3 / 4$ & $3 / 4$ & $1 / 4$ & 4 & n.e. & 4 & n.e. & n.e. & $4 / 7$ & $3 / 4$ & $2 / 4$ & n.e. & $3 / 4$ & $3 / 4$ & 1 \\
\hline СТАTT01 & 1 & 32.4 & 1 & $2 / 4$ & 1 & 1 & 1 & $1 / 4$ & 1 & 1 & 1 & 1 & $1 / 3$ & n.e. & $1 / 3$ & n.e. & n.e. & $1 / 3$ & n.e. & 1 & n.e. & $1 / 2$ & 1 & $0 / 3$ \\
\hline TAGA02 & 4 & 10.3 & 4 & 6 & 4 & 4 & 4 & $4 / 6$ & $4 / 6$ & $4 / 5$ & 4 & $2 / 4$ & $4 / 5$ & n.e. & $4 / 5$ & n.e. & n.e. & $4 / 5$ & 4 & $3 / 4$ & n.e. & $5 / 6$ & $4 / 5$ & $2 / 6$ \\
\hline GGAA05 & 1 & 1.4 & 1 & 6 & 1 & 1 & 5 & 1 & 1 & 1 & 2 & 1 & $2 / 4$ & $1 / 3$ & $1 / 5$ & 5 & $1 / 2$ & $1 / 7$ & $1 / 5$ & $1 / 3$ & $1 / 3$ & $1 / 5$ & $2 / 4$ & $3 / 6$ \\
\hline D16S397 & 1 & 47.1 & n.e. & $1 / 2$ & 1 & 1 & 1 & $0 / 4$ & $1 / 2$ & $1 / 3$ & $1 / 3$ & $2 / 3$ & 1 & n.e. & 1 & n.e. & n.e. & $1 / 4$ & $-3 / 0$ & $-3 / 1$ & n.e. & $-3 / 1$ & 1 & $-3 / 1$ \\
\hline GGAA10 & 3 & 13.2 & 3 & 3 & 3 & 3 & 4 & $3 / 5$ & 3 & 3 & 3 & 3 & 3 & $3 / 6$ & $2 / 3$ & $2 / 4$ & $3 / 7$ & $3 / 5$ & $3 / 8$ & $4 / 6$ & 3 & $3 / 6$ & $3 / 5$ & $3 / 7$ \\
\hline GATA01 & 2 & 44.1 & 2 & $2 / 3$ & 2 & 2 & 2 & 3 & 3 & 3 & 2 & 2 & $1 / 2$ & $2 / 3$ & $1 / 3$ & $3 / 4$ & $1 / 3$ & $1 / 3$ & 1 & 2 & 3 & $1 / 3$ & $2 / 3$ & $2 / 3$ \\
\hline D16S421 & 3 & 75.7 & 3 & 3 & 3 & 3 & 3 & 3 & 3 & 3 & 3 & 3 & 3 & 3 & 3 & 3 & 3 & 3 & 3 & 3 & $3 / 4$ & 3 & 3 & 3 \\
\hline puratrophin-1(C/T) & $\mathbf{T}$ & 0.0 & $\mathrm{~T}$ & $\mathrm{~T}$ & $\mathrm{~T}$ & $\mathrm{~T}$ & $\mathrm{~T}$ & $\mathrm{~T}$ & $\mathrm{~T}$ & $\mathrm{~T} / \mathrm{C}$ & $\mathrm{T} / \mathrm{C}$ & T/C & $\mathrm{T} / \mathrm{C}$ & $\mathrm{T} / \mathrm{C}$ & $\mathrm{T} / \mathrm{C}$ & $\mathrm{T} / \mathrm{C}$ & $\mathrm{T} / \mathrm{C}$ & $\mathrm{T} / \mathrm{C}$ & $\mathrm{T} / \mathrm{C}$ & $\mathrm{T} / \mathrm{C}$ & $\mathrm{T} / \mathrm{C}$ & $\mathrm{T} / \mathrm{C}$ & $\mathrm{T} / \mathrm{C}$ & $\mathrm{T} / \mathrm{C}$ \\
\hline TA001 & 1 & 23.8 & 1 & 1 & 1 & 1 & 1 & 1 & 1 & 1 & 1 & 1 & 1 & $1 / 9$ & $1 / 7$ & $2 / 8$ & $1 / 6$ & $1 / 10$ & $1 / 9$ & $1 / 9$ & 1 & $1 / 9$ & $1 / 9$ & $1 / 5$ \\
\hline GA001 & 4 & 0.1 & 4 & 4 & 4 & 4 & 4 & 4 & 4 & $4 / 7$ & $4 / 7$ & 4 & 4 & $1 / 4$ & $4 / 8$ & $4 / 5$ & $4 / 7$ & $4 / 7$ & $4 / 6$ & $4 / 11$ & $4 / 5$ & $4 / 7$ & $4 / 5$ & $4 / 7$ \\
\hline $17 \mathrm{msm}$ & 2 & 8.3 & 2 & 2 & 2 & 2 & 2 & 2 & 2 & 2 & 2 & 5 & 2 & $2 / 5$ & $2 / 5$ & $2 / 4$ & $2 / 4$ & $2 / 4$ & $2 / 4$ & $2 / 5$ & $2 / 4$ & $2 / 4$ & $4 / 6$ & $2 / 4$ \\
\hline D16S3107 & 7 & 13.9 & 7 & 7 & 7 & 7 & 7 & 7 & 6 & 7 & 7 & 7 & 5 & 6 & $5 / 6$ & $3 / 7$ & $6 / 10$ & 6 & 7 & $5 / 7$ & $3 / 7$ & $6 / 7$ & $4 / 7$ & $6 / 7$ \\
\hline GGAA01 & 6 & 18.8 & 6 & 6 & 6 & 6 & 6 & 6 & 6 & 7 & 6 & 6 & $1 / 6$ & $3 / 6$ & $2 / 6$ & $2 / 6$ & $4 / 6$ & $6 / 7$ & 6 & 6 & 6 & $6 / 7$ & $6 / 7$ & $5 / 6$ \\
\hline CTTT01 & 8 & 28.2 & 8 & 8 & 8 & 8 & $9 / 10$ & 8 & 5 & 9 & 8 & 10 & 8 & $9 / 10$ & $3 / 9$ & $9 / 10$ & $8 / 10$ & 8 & $8 / 11$ & $6 / 9$ & $8 / 15$ & $9 / 10$ & $1 / 7$ & $3 / 8$ \\
\hline GT01 & 6 & 15.8 & 6 & 6 & 6 & 6 & 6 & 6 & 7 & 6 & 6 & 4 & 6 & $2 / 6$ & $1 / 6$ & $4 / 6$ & $4 / 6$ & $2 / 6$ & $5 / 6$ & $4 / 6$ & 6 & $3 / 6$ & $3 / 4$ & $4 / 6$ \\
\hline D16S3095 & 1 & 9.7 & 2 & 3 & 1 & 0 & 1 & 1 & 2 & 3 & 2 & $1 / 2$ & 1 & 1 & $1 / 2$ & $1 / 2$ & $1 / 2$ & $1 / 3$ & 1 & 1 & $1 / 2$ & $1 / 3$ & 2 & 1 \\
\hline D16S512 & 1 & 32.3 & n.e. & $2 / 4$ & 1 & 4 & $1 / 5$ & 4 & $2 / 4$ & $1 / 5$ & $1 / 5$ & $1 / 5$ & 4 & n.e. & $4 / 5$ & n.e. & n.e. & 5 & 1 & $1 / 2$ & n.e. & $2 / 4$ & 4 & $4 / 5$ \\
\hline
\end{tabular}

the SNPs obtained from public databases were not present on the disease allele or did not have enough specificity to the disease chromosome. SNPs were revealed by direct sequencing of the genomic DNA from a homozygous patient who carries the common haplotypes between D16S3031 and GT01 in both of the chromosomes. Primers were designed to amplify about $800 \mathrm{bp}$ from genomic DNA (primer sequences are available on request), and polymerase chain reaction (PCR) and sequencing were performed with the same methods as previously described (Ishikawa et al. 2005). Comparing the sequenced data and the annotated databases with use of DNASIS (Hitachi) software revealed many SNPs. With the sequenced data of the control genomic DNA, SNPs with high specificity to the 16q-ADCAs were chosen. With these SNPs, 16qADCA families were analyzed to reveal the borders of the maximally conserved genomic region.

\section{Results}

Haplotype analysis of 16q-ADCA with the $-16 \mathrm{C}>\mathrm{T}$ substitution in the puratrophin-1 gene

One hundred and twenty-five patients from 64 families were diagnosed as 16q-ADCA based on the clinical features and the presence of the $-16 \mathrm{C}>\mathrm{T}$ substitution in the puratrophin1 gene. The families included 52 families that we had pre- viously reported (Ishikawa et al. 2005) and 12 new families that had not been reported elsewhere. They all share similar haplotypes around the puratrophin-1 gene. The most common haplotype among these families are shown in the left column in Table 1. Twenty-two families out of the 64 families showed different alleles at least for one of the DNA markers as shown in Table 1 . The remaining 42 families, which are not listed in Table 1, harbored or had the possibility to harbor the common haplotype.

There was one repeat-unit difference from the common alleles for D16S397, GGAA10, GATA01, and TA001 close to the puratrophin-1 gene in 13 out of 22 families. For centromeric DNA markers from the puratrophin-1 gene, such as GGAA05, TAGA02, D16S3031, and D16S3043, eight families (P4, P14, T2, T3, T6, T12, T25, T46) harbored alleles with greater differences in repeat number (more than two repeat-units). Furthermore, families P4 and T46 carried different alleles in three consecutive markers, GGAA05, TAGA02, and CTATT01.

Similarly, for telomeric DNA markers such as $17 \mathrm{msm}$, D16S3107, CTTT01, and GT01, greater differences were seen in three families (T12, T15, T44). Especially, families T12 and T44 harbored different alleles for markers 17 msm, CTTT01, and GT01, which were highly specific to the common haplotype.

The presence of large differences in repeat number and successively different alleles would indicate that the families were sharing the common chromosomal region, 
inherited from a founder, between markers GGAA05 and $17 \mathrm{msm}$.

Haplotype analysis of families without identifiable genetic mutations

Twenty-three patients from 22 families presenting pure cerebellar ataxia did not carry identifiable genetic mutations. Nine families showed autosomal dominant inheritance, and the other families had no apparent family history. Their haplotypes are shown in Table 2. Although no family carried entirely identical alleles to the common haplotype consecutively for the markers telomeric to the puratrophin-1 gene, one family (U09) harbored the identical alleles for the markers between D16S3043 and GATA01 centromeric to the puratrophin-1 gene. It suggested the possibility that the U09 family have the common haplotype of 16q-ADCA in the region centromeric to the $-16 \mathrm{C}>\mathrm{T}$ substitution in the puratrophin-1 gene.

\section{Haplotype analysis with SNPs}

Four markers, GGAA05, D16S397, GGAA10, and GATA01 centromeric to the puratrophin-1 gene, showing different alleles in Table 1 suggested that ancestral chromosomal recombination might have occurred around the markers. Family U09 and the family reported by Ohata et al. 2006) also suggested ancestral chromosomal recombination around the substitution in the puratrophin-1 gene. Therefore, we searched the SNPs around these four markers and the puratrophin-1 gene. Five SNPs were

Table 2 The haplotype analysis of families without identifiable genetic mutation. The black squares indicate that the families carry the identical alleles to the common alleles of 16q-ADCA, and the gray squares indicate alleles with one repeat-unit difference. Only identified around the marker GGAA05, one SNP around D16S397, four SNPs around GGAA10, one SNP around GATA01, and two SNPs around the puratrophin-1 gene (Table 3). SNP05 and SNP06 showed high specificity to the disease chromosome because they were absent in 200 control chromosomes.

Eighteen families showed different alleles for GGAA05, D16S397, GGAA10, or GATA01 (Table 1). Among them, sufficient amounts of DNA samples were not available in four families (T25, T26, T30, T42). The remaining 14 families were analyzed as shown in Table 4 . While 13 out of the 14 families carried all of the same SNPs, family T46 did not carry SNP01, SNP02, SNP03, and SNP04. This confirmed that the genomic region between SNP01 and SNP04 of family T46 was a recombinant region, which was not conserved in all families.

These SNPs were also analyzed for the U09 family suspected of having the common haplotype of 16q-ADCA (Table 4). The family had all 13 SNPs, including SNP05 and SNP06, which are highly specific to the disease chromosome. This strongly suggested that family U09 shared the 16q-ADCA common haplotype centromeric to the $-16 \mathrm{C}>\mathrm{T}$ substitution in the puratrophin-1 gene.

\section{Discussion}

16q-ADCA is one of the most common ataxic diseases in Japan. We previously showed that 52 families shared the common haplotype in the genomic 400-kb region between the markers GATA01 and $17 \mathrm{msm}$ by analysis with

family U09 harbored the identical alleles consecutively for the markers from D16S3043 to GATA01, suggesting that this family may harbor the common haplotype of 16q-ADCA. n.c.=notclear. A.D.=autosomal dominant inheritance was suspected

\begin{tabular}{|c|c|c|c|c|c|c|c|c|c|c|c|c|c|c|c|c|c|c|c|c|c|c|c|c|}
\hline Marker & $\begin{array}{c}\text { most } \\
\text { common } \\
\text { aplotype }\end{array}$ & $\begin{array}{c}\text { Family No. } \\
\text { Family history } \\
\begin{array}{c}\text { frequency } \\
\text { in control } \\
(\%)\end{array}\end{array}$ & $\begin{array}{l}\underline{\text { U01 }} \\
\underline{\text { n.c. }}\end{array}$ & $\begin{array}{l}\underline{\text { U02 }} \\
\underline{\text { n.c. }}\end{array}$ & $\begin{array}{l}\underline{\mathrm{U} 03} \\
\underline{\text { n.c. }}\end{array}$ & $\begin{array}{l}\underline{\text { U04 }} \\
\underline{\text { A.D. }}\end{array}$ & $\begin{array}{l}\underline{\text { U05 }} \\
\underline{\text { n.c. }}\end{array}$ & $\begin{array}{l}\underline{\text { U06 }} \\
\underline{\text { n.c. }}\end{array}$ & $\begin{array}{l}\underline{\text { U07 }} \\
\underline{\text { n.c. }}\end{array}$ & $\begin{array}{l}\underline{\text { U08 }} \\
\underline{\text { A.D. }} .\end{array}$ & $\begin{array}{l}\underline{\text { U09 }} \\
\underline{\text { n.c. }}\end{array}$ & $\begin{array}{l}\underline{\text { U10 }} \\
\underline{\text { n.c. }}\end{array}$ & $\begin{array}{l}\underline{\text { U11 }} \\
\underline{\text { A.D. }} .\end{array}$ & $\begin{array}{l}\underline{\text { U12 }} \\
\underline{\text { A.D. }} .\end{array}$ & $\begin{array}{l}\underline{\text { U13 }} \\
\underline{\text { A.D. }} .\end{array}$ & $\begin{array}{l}\underline{\text { U14 }} \\
\underline{\text { n.c. }}\end{array}$ & $\begin{array}{l}\underline{\text { U15 }} \\
\underline{\text { A.D. }} .\end{array}$ & $\begin{array}{l}\underline{\text { U16 }} \\
\underline{\text { A.D. }}\end{array}$ & $\begin{array}{l}\underline{\text { U17 }} \\
\underline{\text { A.D. }}\end{array}$ & $\begin{array}{l}\underline{\text { U18 }} \\
\underline{\text { A.D. }}\end{array}$ & $\begin{array}{l}\underline{\text { U19 }} \\
\underline{\text { n.c. }}\end{array}$ & $\begin{array}{l}\underline{\text { U20 }} \\
\underline{\text { n.c. }}\end{array}$ & $\begin{array}{l}\text { U21 } \\
\text { n.c. }\end{array}$ & $\begin{array}{l}\underline{\text { U22 }} \\
\underline{\text { n.c. }}\end{array}$ \\
\hline D16S3043 & 1 & 25.0 & $1 / 6$ & $4 / 8$ & $1 / 2$ & $1 / 7$ & 1 & $4 / 6$ & 5 & 5 & $1 / 7$ & $1 / 7$ & $4 / 5$ & $4 / 5$ & $1 / 6$ & $1 / 5$ & 5 & $1 / 6$ & $5 / 7$ & $1 / 6$ & 1 & 1 & $1 / 5$ & $1 / 8$ \\
\hline D16S3019 & 4 & 41.4 & & $1 / 4$ & 4 & 1 & $3 / 4$ & 5 & $3 / 4$ & 4 & 4 & $3 / 4$ & 1 & 2 & 4 & $4 / 5$ & $4 / 5$ & $3 / 4$ & 1 & 2 & 1 & 1 & $1 / 3$ & $1 / 2$ \\
\hline CTATT01 & 1 & 32.4 & $3 / 4$ & $1 / 4$ & $1 / 3$ & 3 & $2 / 4$ & $1 / 2$ & 3 & 3 & $1 / 4$ & $1 / 3$ & $1 / 3$ & $1 / 3$ & 4 & 1 & $1 / 3$ & $2 / 5$ & 1 & $2 / 3$ & $1 / 3$ & $1 / 2$ & 1 & $1 / 3$ \\
\hline TAGA02 & 4 & 10.3 & $3 / 5$ & 6 & $2 / 4$ & $4 / 5$ & $5 / 6$ & $4 / 6$ & $5 / 6$ & $5 / 6$ & $4 / 5$ & 5 & 5 & $6 / 7$ & 5 & $2 / 6$ & $3 / 5$ & $4 / 5$ & 6 & $4 / 5$ & $4 / 6$ & $3 / 6$ & $2 / 6$ & $5 / 6$ \\
\hline GGAA05 & 1 & 1.4 & 3 & $4 / 5$ & $4 / 5$ & 4 & 5 & $3 / 4$ & $4 / 6$ & 4 & $1 / 3$ & 3 & $2 / 4$ & 4 & 4 & 5 & $4 / 5$ & $2 / 6$ & 4 & $4 / 5$ & $4 / 6$ & $5 / 6$ & $4 / 6$ & $4 / 5$ \\
\hline D16S397 & 1 & 47.1 & $-1 / 1$ & $1 / 3$ & $2 / 3$ & $4 / 6$ & 4 & 1 & 3 & 4 & 1 & 3 & $1 / 4$ & 1 & 1 & $1 / 2$ & $1 / 4$ & $3 / 5$ & $1 / 4$ & $2 / 6$ & 1 & $-3 / 3$ & $1 / 3$ & $-3 / 6$ \\
\hline D16S3086 & 2 & 65.7 & 2 & $2 / 3$ & $3 / 4$ & $3 / 4$ & 3 & 2 & 3 & 3 & 2 & 3 & $2 / 4$ & 2 & 2 & 2 & $2 / 3$ & $2 / 3$ & & & & 3 & $2 / 3$ & $3 / 4$ \\
\hline GATA01 & 2 & 44.1 & 2 & $1 / 2$ & $1 / 3$ & $2 / 4$ & 3 & 3 & $1 / 3$ & 3 & $1 / 2$ & $2 / 3$ & 2 & $2 / 3$ & 2 & $2 / 3$ & $2 / 3$ & 2 & 1 & $0 / 2$ & $3 / 4$ & 2 & 1 & $0 / 2$ \\
\hline puratrophin-1 $(\mathrm{C} / \mathrm{T})$ & ) $T$ & 0.0 & $\mathrm{C}$ & $\mathrm{C}$ & $\mathrm{C}$ & $\mathrm{C}$ & C & C & C & C & $\mathrm{C}$ & $\mathrm{C}$ & $\mathrm{C}$ & C & C & C & $C$ & $\mathrm{C}$ & C & C & C & $\mathrm{C}$ & C & $\mathrm{C}$ \\
\hline GA001 & 4 & 0.1 & $1 / 8$ & $6 / 8$ & 8 & $8 / 9$ & 8 & $7 / 11$ & $8 / 9$ & 1 & $5 / 7$ & $7 / 10$ & $6 / 7$ & $5 / 8$ & 5 & $5 / 8$ & $5 / 9$ & $1 / 7$ & $6 / 7$ & $5 / 7$ & $6 / 9$ & $6 / 8$ & $7 / 9$ & $7 / 8$ \\
\hline $17 \mathrm{msm}$ & 2 & 8.3 & $3 / 4$ & 4 & $4 / 5$ & $4 / 5$ & 5 & $2 / 6$ & 5 & 2 & 5 & $3 / 4$ & 4 & $3 / 4$ & 4 & $1 / 3$ & $2 / 4$ & 7 & 5 & $2 / 6$ & 4 & $2 / 4$ & $4 / 5$ & $2 / 5$ \\
\hline CTTT01 & 8 & 28.2 & $5 / 7$ & $8 / 10$ & $6 / 10$ & $6 / 9$ & $4 / 5$ & $7 / 10$ & $5 / 6$ & 9 & $5 / 10$ & $6 / 7$ & 9 & $7 / 9$ & $5 / 6$ & $7 / 8$ & $7 / 10$ & $5 / 11$ & $5 / 7$ & $7 / 10$ & $8 / 10$ & $4 / 7$ & $6 / 8$ & $7 / 9$ \\
\hline GT01 & 6 & 15.8 & $2 / 4$ & $4 / 6$ & $2 / 6$ & $2 / 4$ & $2 / 5$ & $1 / 2$ & $2 / 3$ & 7 & $2 / 4$ & $2 / 6$ & $1 / 4$ & $4 / 6$ & $3 / 4$ & 4 & $2 / 6$ & $3 / 4$ & $4 / 7$ & $2 / 6$ & $3 / 6$ & $4 / 6$ & $5 / 8$ & 2 \\
\hline D16S3095 & 1 & 9.7 & 2 & $1 / 3$ & $2 / 3$ & $2 / 5$ & $1 / 3$ & $2 / 3$ & $2 / 4$ & 6 & 2 & $2 / 3$ & $2 / 4$ & $1 / 2$ & 3 & $2 / 3$ & $1 / 2$ & $1 / 3$ & $3 / 4$ & $3 / 4$ & $1 / 2$ & $2 / 6$ & $2 / 4$ & $2 / 4$ \\
\hline D16S512 & 1 & 32.3 & $2 / 4$ & $1 / 5$ & $4 / 5$ & $2 / 4$ & $2 / 4$ & 4 & $2 / 4$ & 1 & 2 & $2 / 4$ & $1 / 4$ & $4 / 5$ & 4 & $2 / 4$ & 4 & $2 / 3$ & $1 / 4$ & 2 & $4 / 5$ & $4 / 5$ & $4 / 5$ & 4 \\
\hline
\end{tabular}


Table 3 Single nucleotide polymorphisms (SNPs) on the disease chromosome of 16q22.1-linked autosomal dominant cerebellar ataxia (16q-ADCA). We identified thirteen SNPs by ourselves. SNP05 and SNP06 were absent in control chromosomes $(n=200)$ and are thought to be highly specific to the disease chromosome

\begin{tabular}{|c|c|c|c|c|}
\hline $\mathrm{SNP} /$ marker & & $\begin{array}{l}\text { Position } \\
\text { on Chr } 16\end{array}$ & $\begin{array}{l}\text { SNP change on } \\
16 \mathrm{q}-\mathrm{ADCA}\end{array}$ & $\begin{array}{l}\text { Frequency in } \\
\text { control }(\%)\end{array}$ \\
\hline & GGAA05 & $64,938,933$ & & \\
\hline SNP01 & & $64,972,150$ & $\mathrm{~A} \rightarrow \mathrm{G}$ & 27.8 \\
\hline SNP02 & & $64,977,170$ & $\mathrm{~A} \rightarrow \mathrm{C}$ & 22.2 \\
\hline SNP03 & & $64,977,733$ & $\mathrm{~T} \rightarrow \mathrm{C}$ & 30.0 \\
\hline SNP04 & & $64,982,678$ & $\mathrm{C} \rightarrow \mathrm{T}$ & 27.8 \\
\hline \multirow[t]{2}{*}{ SNP05 } & & $65,049,292$ & $\mathrm{G} \rightarrow \mathrm{A}$ & 0.0 \\
\hline & D16S397 & $65,295,770$ & & \\
\hline SNP06 & & $65,337,827$ & $\mathrm{~A} \rightarrow \mathrm{G}$ & 0.0 \\
\hline SNP07 & & $65,449,825$ & $\mathrm{C} \rightarrow \mathrm{T}$ & 56.3 \\
\hline \multirow[t]{2}{*}{ SNP08 } & & $65,451,833$ & $\mathrm{~T} \rightarrow \mathrm{A}$ & 45.5 \\
\hline & GGAA10 & $65,452,426$ & & \\
\hline SNP09 & & $65,457,741$ & $\mathrm{~T} \rightarrow \mathrm{A}$ & 42.4 \\
\hline SNP10 & & $65,458,302$ & $\mathrm{~T} \rightarrow \mathrm{C}$ & 45.5 \\
\hline \multirow[t]{2}{*}{ SNP11 } & & $65,669,454$ & $\mathrm{~T} \rightarrow \mathrm{C}$ & 30.3 \\
\hline & GATA01 & $65,700,022$ & & \\
\hline SNP12 & & $65,771,917$ & $\mathrm{G} \rightarrow \mathrm{A}$ & 18.2 \\
\hline SNP13 & & $65,793,152$ & $\mathrm{C} \rightarrow \mathrm{T}$ & 8.7 \\
\hline $\begin{array}{c}\text { puratrophin- } \\
1(\mathrm{C} / \mathrm{T})\end{array}$ & & $65,871,434$ & $\mathrm{C} \rightarrow \mathrm{T}$ & 0.0 \\
\hline
\end{tabular}

Table 4 The haplotype analysis with single nucleotide polymorphisms (SNPs). Fourteen familiesof 16q-ADCA with different alleles for microsatellite markers and family U09 are shown.The gray squares indicate that the family carried the SNPs common to $16 \mathrm{q}-$ ADCA. Family T46 did not carry the common SNPs from SNP01 to SNP04. This is consistent with the findingon microsatellite markers microsatellite markers. Within this region, we had found that the single nucleotide $-16 \mathrm{C}>\mathrm{T}$ substitution in the $p u$ ratrophin-1 gene was strongly associated with the disease (Ishikawa et al. 2005). Since then, a number of patients with the substitution and the common haplotype were reported in various areas of Japan. However, a report of the one exceptional patient without the substitution in the family in which all other affected subjects carried the substitution (Ohata et al. 2006) raised the possibility that a true pathogenic mutation may be present in a different gene. This exceptional patient indicated that the mutation might be lying centromeric to the substitution in the $p u$ ratrophin-1 gene, where the patient shared the common haplotype with other affected individuals in the family.

Here, we re-examined the 16q-ADCA families with the $-16 \mathrm{C}>\mathrm{T}$ substitution in the puratrophin-1 gene with microsatellite markers and found four possible centromeric borders of the disease locus (GATA01, D16S397, GGAA10, GGAA05), based on the difference of alleles. We searched for informative SNPs around the markers capable of distinguishing the chromosomes derived from a founder and analyzed haplotypes with the SNPs. Because all of the examined families carried SNPs around the markers GATA01, D16S397, and GGAA10, ancestral chromosomal recombination around the markers was not confirmed. The differences in alleles for these markers was only one repeat-unit, suggesting that the allele differences

(Table 1), further suggesting that the centromeric border of thedisease locus is SNP04. Family U09 carried all of the 13 SNPs. This would also supportthe theory that family U09 shares the 16q-ADCA common haplotype centromeric to the substitution inthe puratrophin-1 gene

\begin{tabular}{|c|c|c|c|c|c|c|c|c|c|c|c|c|c|c|c|c|c|c|}
\hline \multirow{3}{*}{$\begin{array}{l}\text { SNP } \\
\text { SNP01 }\end{array}$} & \multirow{2}{*}{\multicolumn{2}{|c|}{$\begin{array}{l}\text { SNP change on } \\
\text { 16q-ADCA }\end{array}$}} & \multirow{3}{*}{$\begin{array}{c}\begin{array}{c}\text { frequency } \\
\text { in control } \\
(\%)\end{array} \\
27.8\end{array}$} & \multicolumn{15}{|c|}{ family No. } \\
\hline & & & & $\underline{\mathbf{P 4}}$ & $\underline{\mathbf{T 3}}$ & $\underline{\text { T4 }}$ & $\underline{\text { T5 }}$ & $\underline{\text { T6 }}$ & $\underline{\mathrm{T} 7}$ & $\underline{\mathbf{T 1 2}}$ & $\underline{\mathbf{T 1 5}}$ & T21 & $\underline{T 28}$ & T37 & $\underline{\mathbf{T 4 3}}$ & $\underline{\mathrm{T} 44}$ & $\underline{\mathrm{T} 46}$ & $\underline{\text { U09 }}$ \\
\hline & $\mathbf{A} \rightarrow$ & G & & G/A & G/A & G/A & G & G & G/A & G & G/A & G/A & G/A & G & G/A & G & $\mathbf{A}$ & G/A \\
\hline SNP02 & $\mathbf{A} \rightarrow$ & C & 22.2 & C/A & C/A & C/A & C & C & C/A & C & C/A & C/A & C/A & C & C/A & C/A & $\mathbf{A}$ & C/A \\
\hline SNP03 & $\mathrm{T} \rightarrow$ & C & 30.0 & $\mathrm{C} / \mathrm{T}$ & $\mathrm{C} / \mathrm{T}$ & $\mathrm{C} / \mathrm{T}$ & C & C & $\mathrm{C} / \mathrm{T}$ & C & $\mathrm{C} / \mathrm{T}$ & $\mathrm{C} / \mathrm{T}$ & $\mathrm{C} / \mathrm{T}$ & C & $\mathrm{C} / \mathrm{T}$ & C & $\mathbf{T}$ & $\mathrm{C} / \mathrm{T}$ \\
\hline SNP04 & $\mathrm{C} \rightarrow$ & $\mathbf{T}$ & 27.8 & T/C & $\mathbf{T}$ & $\mathbf{T} / \mathbf{C}$ & $\mathbf{T}$ & $\mathbf{T}$ & $\mathrm{T} / \mathrm{C}$ & $\mathbf{T}$ & $\mathrm{T} / \mathrm{C}$ & T/C & $\mathbf{T}$ & $\mathbf{T}$ & $\mathrm{T} / \mathrm{C}$ & $\mathbf{T}$ & C & $\mathrm{C} / \mathrm{T}$ \\
\hline SNP05 & $\mathbf{G} \rightarrow$ & $\mathbf{A}$ & 0.0 & A/G & A/G & A/G & A/G & A/G & A/G & A/G & A/G & A/G & A/G & A/G & A/G & A/G & A/G & A/G \\
\hline SNP06 & $\mathbf{A} \rightarrow$ & G & 0.0 & G/A & G/A & G/A & G/A & G/A & G/A & G/A & G/A & G/A & G/A & G/A & G/A & G/A & G/A & G/A \\
\hline SNP07 & $\mathrm{C} \rightarrow$ & $\mathbf{T}$ & 56.3 & $\mathbf{T}$ & $\mathbf{T} / \mathbf{C}$ & $\mathrm{T} / \mathrm{C}$ & $\mathbf{T}$ & $\mathbf{T}$ & $\mathrm{T} / \mathrm{C}$ & $\mathbf{T} / \mathbf{C}$ & $\mathbf{T}$ & $\mathbf{T}$ & $\mathrm{T} / \mathrm{C}$ & $\mathrm{T} / \mathrm{C}$ & $\mathrm{T} / \mathrm{C}$ & $\mathbf{T}$ & $\mathrm{T} / \mathrm{C}$ & T/C \\
\hline SNP08 & $\mathrm{T} \rightarrow$ & $\mathbf{A}$ & 45.5 & $\mathbf{A}$ & $\mathbf{A} / \mathbf{T}$ & $\mathbf{A} / \mathbf{T}$ & $\mathbf{A}$ & $\mathbf{A}$ & $\mathbf{A} / \mathbf{T}$ & $\mathbf{A} / \mathbf{T}$ & $\mathbf{A}$ & $\mathbf{A}$ & $\mathbf{A} / \mathbf{T}$ & $\mathbf{A} / \mathbf{T}$ & $\mathbf{A} / \mathbf{T}$ & $\mathbf{A}$ & $\mathbf{A} / \mathbf{T}$ & $\mathbf{A}$ \\
\hline SNP09 & $\mathbf{T} \rightarrow$ & $\mathbf{A}$ & 42.4 & $\mathbf{A}$ & $\mathbf{A} / \mathbf{T}$ & $\mathbf{A} / \mathbf{T}$ & $\mathbf{A}$ & $\mathbf{A}$ & $\mathbf{A} / \mathbf{T}$ & $\mathbf{A} / \mathbf{T}$ & $\mathbf{A}$ & $\mathbf{A}$ & $\mathbf{A} / \mathbf{T}$ & $\mathbf{A} / \mathbf{T}$ & $\mathbf{A} / \mathbf{T}$ & $\mathbf{A}$ & $\mathbf{A} / \mathbf{T}$ & $\mathbf{A}$ \\
\hline SNP10 & $\mathbf{T} \rightarrow$ & C & 45.5 & C & $\mathrm{C} / \mathrm{T}$ & $\mathrm{C} / \mathrm{T}$ & C & C & $\mathrm{C} / \mathrm{T}$ & $\mathrm{C} / \mathrm{T}$ & C & C & $\mathrm{C} / \mathrm{T}$ & $\mathrm{C} / \mathrm{T}$ & $\mathrm{C} / \mathrm{T}$ & $\mathrm{C} / \mathrm{T}$ & $\mathrm{C} / \mathrm{T}$ & C \\
\hline SNP11 & $\mathbf{T} \rightarrow$ & $\mathrm{C}$ & 30.3 & C & $\mathrm{C} / \mathrm{T}$ & $\mathrm{C} / \mathrm{T}$ & $\mathrm{C} / \mathrm{T}$ & C & $\mathrm{C} / \mathrm{T}$ & C & $\mathrm{C}$ & $\mathrm{C} / \mathrm{T}$ & $\mathrm{C} / \mathrm{T}$ & $\mathrm{C} / \mathrm{T}$ & $\mathrm{C} / \mathrm{T}$ & C & $\mathrm{C} / \mathrm{T}$ & $\mathrm{C} / \mathrm{T}$ \\
\hline SNP12 & $\mathbf{G} \rightarrow$ & $\mathbf{A}$ & 18.2 & $\mathbf{A}$ & A/G & $\mathbf{A} / \mathbf{G}$ & $\mathbf{A} / \mathbf{G}$ & $\mathbf{A} / \mathbf{G}$ & A/G & A/G & $\mathbf{A}$ & $\mathbf{A} / \mathbf{G}$ & A/G & A/G & A/G & $\mathbf{A}$ & $\mathbf{A} / \mathbf{G}$ & A/G \\
\hline SNP13 & $\mathrm{C} \rightarrow$ & $\mathbf{T}$ & 8.7 & $\mathbf{T}$ & $\mathrm{C} / \mathrm{T}$ & $\mathrm{C} / \mathrm{T}$ & $\mathrm{C} / \mathrm{T}$ & $\mathrm{C} / \mathrm{T}$ & $\mathrm{C} / \mathrm{T}$ & $\mathrm{C} / \mathrm{T}$ & $\mathrm{C} / \mathrm{T}$ & $\mathrm{C} / \mathrm{T}$ & $\mathrm{C} / \mathrm{T}$ & $\mathrm{C} / \mathrm{T}$ & $\mathrm{C} / \mathrm{T}$ & $\mathbf{T}$ & $\mathrm{C} / \mathrm{T}$ & $\mathrm{C} / \mathrm{T}$ \\
\hline puratrophin-1(C/T) & $\mathrm{C} \rightarrow$ & $\mathbf{T}$ & 0.0 & $\mathbf{T}$ & $\mathbf{T}$ & $\mathbf{T}$ & $\mathbf{T}$ & $\mathbf{T} / \mathbf{C}$ & $\mathbf{T} / \mathrm{C}$ & $\mathbf{T} / \mathbf{C}$ & T/C & T/C & $\mathbf{T} / \mathrm{C}$ & $\mathrm{T} / \mathrm{C}$ & $\mathbf{T} / \mathrm{C}$ & $\mathrm{T} / \mathrm{C}$ & $\mathrm{T} / \mathrm{C}$ & C \\
\hline
\end{tabular}


in GATA01, D16S397, and GGAA10 might have resulted not from recombination events, but from the microsatellite slippage mutation (Ikeda et al. 2004). On the other hand, four families (P4, T3, T25, T46) showed great allele differences in GGAA05 and one family (T46) did not carry four SNPs, confirming that family T46 did not share the genomic region centromeric to GGAA05 with the other 16q-ADCA families. This strongly indicates that the centromeric border of the disease locus of 16q-ADCA could be placed at SNP04.

The U09 family had the identical alleles for all markers and SNPs in the region centromeric to the $-16 \mathrm{C}>\mathrm{T}$ substitution in the puratrophin-1 gene. It is impossible to conclude that the family has the common haplotype of 16qADCA because only one examined family member was available for the present genetic analysis. However, carrying the rare alleles for GGAA05 and infrequent SNPs, both highly specific to the disease chromosome, strongly suggests that the U09 family shares a part of the 16qADCA common haplotype. The patient in the U09 family developed pure cerebellar ataxia later in life without apparent family history. Because 16q-ADCA patients were found among sporadic cases (Ouyang et al. 2006), these clinical features of the U09 family are consistent with those of 16q-ADCA. Importantly, this family had not been reported previously and, therefore, would be the second case of 16q-ADCA without the substitution in the puratrophin-1 gene following the family reported by Ohata et al. (2006). These cases indicate that the telomeric end of the disease locus could be placed at the $-16 \mathrm{C}>\mathrm{T}$ substitution in the puratrophin-1 gene.

Haplotype analysis of a number of 16q-ADCA families with microsatellite markers and SNPs in this study suggests

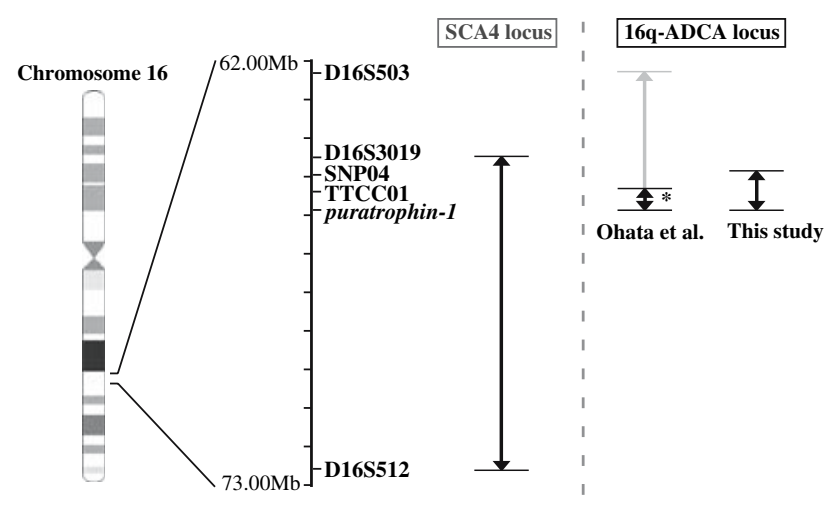

Fig. 1 A summary of critical intervals for 16q-ADCA and SCA4. Our study could define the disease locus of 16q-ADCA to a 900-kb genomic region between SNP04 and the $-16 \mathrm{C}>\mathrm{T}$ substitution in the puratrophin-1 gene. This region is completely inside the candidate locus of SCA4 (Flanigan et al. 1996).The haplotype region (asterisk) between TTCC01 and the puratrophin-1 gene shown by Ohata et al. (2006) is also shown, together with an alternative critical region between D16S503 and the puratrophin-1 gene (see text for details) that the gene locus of 16q-ADCA could be re-assigned to a 900-kb genomic region between SNP04 and the substitution in the puratrophin-1 gene (Fig. 1). This region partly overlaps with, but is not the same as, the candidate region previously set by Ohata et al. (2006). They showed that three large 16q-ADCA families shared a common haplotype between D16S3086 and D16S412, and suggested the possibility that real pathogenic mutation would exist in the region between TTCC 01 and the $-16 \mathrm{C}>\mathrm{T}$ substitution in the puratrophin-1 gene. However, the allele difference for TTCC01 in their families was only one repeat-unit, and all of their patients shared identical allele for TAGA02, lying centromeric to TTCC01. Since the possibility of slippage mutation remains as an explanation for the allele difference seen in TTCC01, as we observed for GATA01, D16S397, and GGAA10, it would be cautious to place the centromeric border at the marker TTCC01. Given that the allele differences in TTCCO1 is due to slippage mutation, the centromeric border in their families would be alternatively set at D16S503, since an obligate recombination was seen between D16S503 and TAGA02. It would be, thus, important to analyze GGAA05 and specific SNPs in their families to see to what extent their patients harbor conserved haplotypes.

Although we found a patient without the $-16 \mathrm{C}>\mathrm{T}$ substitution in the puratrophin-1 gene, the substitution was present in all patients except the one in the U09 family (i.e., $125 / 126=99.2 \%$ sensitivity; $100 \%$ specificity) and, thus, the puratrophin-1 genetic change still remains to be a useful marker. Molecular diagnosis with multiple microsatellite markers and SNPs will help to identify 16q-ADCA patients more accurately. Through the present study, we showed that the truly pathogenic mutation would lie in a $900-\mathrm{kb}$ genomic region between SNP04 and the $-16 \mathrm{C}>\mathrm{T}$ substitution in the puratrophin-1 gene. Further investigations for finding a genetic mutation within the critical region are needed to elucidate the molecular pathogenesis of 16q-ADCA.

\section{References}

Cagnoli C, Mariotti C, Taroni F, Seri M, Brussino A, Michielotto C, Grisoli M, Di Bella D, Migone N, Gellera C, Di Donato S, Brusco A (2006) SCA28, a novel form of autosomal dominant cerebellar ataxia on chromosome 18p11.22-q11.2. Brain 129:235-242

Chen DH, Brkanac Z, Verlinde CL, Tan XJ, Bylenok L, Nochlin D,Matsushita M, Lipe H, Wolff J, Fernandez M, Cimino PJ, Bird TD,Raskind WH (2003) Missense mutations in the regulatory domain of PKC gamma: a new mechanism for dominant nonepisodic cerebellar ataxia. AmJ Hum Genet 72:839-849

Flanigan K, Gardner K, Alderson K, Galster B, Otterud B, Leppert MF, Kaplan C, Ptacek LJ (1996) Autosomal dominant spinocerebellar ataxia with sensory axonal neuropathy (SCA4): clinical description and genetic localization to chromosome 16q22.1. Am J Hum Genet 59:392-399 
Harding AE (1982) The clinical features and classification of the late onset autosomal dominant cerebellar ataxias. A study of 11 families, including descendants of the "Drew family of Walworth." Brain 105:1-28

Hellenbroich Y, Pawlack H, Rub U, Schwinger E, Zuhlke Ch (2005) Spinocerebellar ataxia type 4 . Investigation of 34 candidate genes. J Neurol 252:1472-1475

Holmes SE, O'Hearn EE, McInnis MG, Gorelick-Feldman DA, Kleiderlein JJ, Callahan C, Kwak NG, Ingersoll-Ashworth RG, Sherr M, Sumner AJ, Sharp AH, Ananth U, Seltzer WK, Boss MA, Vieria-Saecker A-M, Epplen JT, Riess O, Ross CA, Margolis RL (1999) Expansion of a novel CAG trinucleotide repeat in the $5^{\prime}$ region of PPP2R2B is associated with SCA12. Nat Genet 23:391-392

Ikeda Y, Dalton JC, Moseley ML, Gardner KL, Bird TD, Ashizawa T, Seltzer WK, Pandolfo M, Milunsky A, Potter NT, Shoji M, Vincent JB, Day JW, Ranum LP (2004) Spinocerebellar ataxia type 8: molecular genetic comparisons and haplotype analysis of 37 families with ataxia. Am J Hum Genet 75:3-16

Ikeda Y, Dick KA, Weatherspoon MR, Gincel D, Armbrust KR, Dalton JC, Stevanin G, Durr A, Zuhlke C, Burk K, Clark HB, Brice A, Rothstein JD, Schut LJ, Day JW, Ranum LP (2006) Spectrin mutations cause spinocerebellar ataxia type 5. Nat Genet 38:184-190

Ishikawa K, Tanaka H, Saito M, Ohkoshi N, Fujita T, Yoshizawa K,Ikeuchi T, Watanabe M, Hayashi A, Takiyama Y, Nishizawa M, Nakano I,Matsubayashi K, Miwa M, Shoji S, Kanazawa I, Tsuji S, Mizusawa H(1997) Japanese families with autosomal dominant pure cerebellar ataxia map to chromosome 19p13.1p13.2 and are strongly associated with mild CAG expansions in the spinocerebellar ataxia type 6 gene in chromosome $19 \mathrm{p} 13.1$. Am J Hum Genet 61:336-346

Ishikawa $\mathrm{K}$, Toru $\mathrm{S}$, Tsunemi $\mathrm{T}$, Li M, Kobayashi $\mathrm{K}$, Yokota $\mathrm{T}$, Amino T, Owada K, Fujigasaki H, Sakamoto M, Tomimitsu H, Takashima M, Kumagai J, Noguchi Y, Kawashima Y, Ohkoshi N, Ishida G, Gomyoda M, Yoshida M, Hashizume Y, Saito Y, Murayama S, Yamanouchi H, Mizutani T, Kondo I, Toda T, Mizusawa H (2005) An autosomal dominant cerebellar ataxia linked to chromosome $16 \mathrm{q} 22.1$ is associated with a singlenucleotide substitution in the $5^{\prime}$ untranslated region of the gene encoding a protein with spectrin repeat and Rho guanine nucleotide exchange-factor domains. Am J Hum Genet 77:280-296

Koob MD, Moseley ML, Schut LJ, Benzow KA, Bird TD, Day JW, Ranum LP (1999) An untranslated CTG expansion causes a novel form of spinocerebellar ataxia (SCA8). Nat Genet 21:379-384

Matsuura T, Yamagata T, Burgess DL, Rasmussen A, Grewal RP, Watase K, Khajavi M, McCall AE, Davis CF, Zu L, Achari M, Pulst SM, Alonso E, Noebels JL, Nelson DL, Zoghbi HY, Ashizawa T (2000) Large expansion of the ATTCT pentanucleotide repeat in spinocerebellar ataxia type 10. Nat Genet 26:191194

Nagaoka U, Takashima M, Ishikawa K, Yoshizawa K, Yoshizawa T, Ishikawa M, Yamawaki T, Shoji S, Mizusawa H (2000) A gene on SCA4 locus causes dominantly inherited pure cerebellar ataxia. Neurology 54:1971-1975

Ohata T, Yoshida K, Sakai H, Hamanoue H, Mizuguchi T, Shimizu Y, Okano T, Takada F, Ishikawa K, Mizusawa H, Yoshiura K, Fukushima Y, Ikeda S, Matsumoto N (2006) A $-16 \mathrm{C}>\mathrm{T}$ substitution in the $5^{\prime}$ UTR of the puratrophin-1 gene is prevalent in autosomal dominant cerebellar ataxia in Nagano. J Hum Genet 51:461-466

Onodera Y, Aoki M, Mizuno H, Warita H, Shiga Y, Itoyama Y (2006) Clinical features of chromosome 16q22.1 linked autosomal dominant cerebellar ataxia in Japanese. Neurology 67:13001302

Ouyang Y, Sakoe K, Shimazaki H, Namekawa M, Ogawa T, Ando Y, Kawakami T, Kaneko J, Hasegawa Y, Yoshizawa K, Amino T, Ishikawa K, Mizusawa H, Nakano I, Takiyama Y (2006) 16qlinked autosomal dominant cerebellar ataxia: a clinical and genetic study. J Neurol Sci 247:180-186

Ross CA, Poirier MA (2004) Protein aggregation and neurodegenerative disease. Nat Med 10 Suppl:S10-S17

Sasaki H, Yabe I, Tashiro K (2003) The hereditary spinocerebellar ataxias in Japan. Cytogenet Genome Res 100:198-205

Schöls L, Bauer P, Schmidt T, Schulte T, Riess O (2004) Autosomal dominant cerebellar ataxias: clinical features, genetics, and pathogenesis. Lancet Neurol 3:291-304

van Swieten JC, Brusse E, de Graaf BM, Krieger E, van de Graaf R, deKoning I, Maat-Kievit A, Leegwater P, Dooijes D, Oostra BA, Heutink $\mathrm{P}(2003)$ A mutation in the fibroblast growth factor 14 gene is associated with autosomal dominant cerebellar ataxia. Am J Hum Genet72:191-199

Takano H, Cancel G, Ikeuchi T, Lorenzetti D, Mawad R, Stevanin G, Didierjean O, Durr A, Oyake M, Shimohata T, Sasaki R, Koide R, Igarashi S, Hayashi S, Takiyama Y, Nishizawa M, Tanaka H, Zoghbi H, Brice A, Tsuji S (1998) Close associations between prevalences of dominantly inherited spinocerebellar ataxias with CAG-repeat expansions and frequencies of large normal CAG alleles in Japanese and Caucasian populations. Am J Hum Genet 63:1060-1066

Takashima M, Ishikawa K, Nagaoka U, Shoji S, Mizusawa H (2001) A linkage disequilibrium at the candidate gene locus for $16 \mathrm{q}-$ linked autosomal dominant cerebellar ataxia type III in Japan. J Hum Genet 46:167-171

Waters MF, Minassian NA, Stevanin G, Figueroa KP, Bannister JP, Nolte D, Mock AF, Evidente VG, Fee DB, Muller U, Durr A, Brice A, Papazian DM, Pulst SM (2006) Mutations in voltagegated potassium channel $\mathrm{KCNC} 3$ cause degenerative and developmental central nervous system phenotypes. Nat Genet 38:447-451

Wieczorek S, Arning L, Alheite I, Epplen JT (2006) Mutations of the puratrophin-1 (PLEKHG4) gene on chromosome 16q22.1 are not a common genetic cause of cerebellar ataxia in a European population. J Hum Genet 51: 363-367

Yu GY, Howell MJ, Roller MJ, Xie TD, Gomez CM (2005) Spinocerebellar ataxia type 26 maps to chromosome $19 \mathrm{p} 13.3$ adjacent to SCA6. Ann Neurol 57:349-354 